\title{
OPTIMALISASI HUBUNGAN ANTARGEREJA DI DOYO SENTANI SEBAGAI UPAYA MENUNJANG KEESAAN GEREJA
}

\author{
Otinel Kaway ${ }^{1}$ \\ Daniel Ronda ${ }^{2}$
}

\begin{abstract}
ABSTRAK
Tujuan penulisan adalah untuk mengetahui pengaruh kerjasama dalam persekutuan bersama antargereja dapat mengoptimalkan sesuatu yang berguna untuk mambawa perubahan dalam gereja-gereja lokal di Doyo Sentani

Metode penelitian yang digunakan adalah: Pertama, studi kepustakaan yang mendukung pembahasan tulisan ilmiah ini. Kedua, melalui angket yang disebarkan ke seratus responden, guna mendapat masukan dan sekaligus menjadi dasar yang menguatkan penelitian serta memiliki bobot ilmiah. Ketiga, wawancara, yaitu melakukan percakapan langsung atau wawancara melalui beberapa pertanyaan lisan kepada responden atau anggota jemaat juga kepada pemimpin dalam jemaat (pendeta, penatua, syamas, majelis) yang dituakan dan sebagai panutan dalam jemaat di tujuh denominasi gereja yang ada di Doyo Sentani.

Kesimpulan penelitian ini adalah: Pertama, Kesatuan dalam hubungan kerjasama pelayanan antargereja di Doyo Sentani dapat tercipta apabila semua orang percaya sungguh-sungguh memahami arti persekutuan yang dimaksudkan oleh Tuhan Yesus Kristus. Kedua, Hubungan antargereja sebagai upaya dan sarana untuk mengkomunikasikan Injil Yesus Kristus bagi anggota jemaat yang tidak aktif, serta meningkatkan mutu rohani jemaat secara menyeluruh. Ketiga, Optimalisasi hubungan kerjasama pelayanan melalui persekutuan bersama antargereja lokal di Doyo Sentani dapat dicapai karena hal itu merupakan kebutuhan. Pemimpin gereja dan anggota jemaat yang memahami kepentingan dari persekutuan bersama dapat mewujudkannya melalui pengoptimalisasian hubungan kerjasama antargereja lokal di Doyo.
\end{abstract}

Kata kunci: optimalisasi hubungan, Doyo Sentani, keesaan gereja

\footnotetext{
${ }^{1}$ Alumni Pascasarjana STT Jaffray Makassar 2013; Beliau juaga adalah Ketua STT Levinus Rumaseb Jayapura.

${ }^{2}$ Staf Dosen Pascasarjana STT Jaffray Makassar; Ketua STT Jaffray Makassar.
} 


\section{PENDAHULUAN}

\section{Latar Belakang Masalah}

Gereja-gereja di Doyo Sentani selama ini kurang menjalin relasi yang formal, sehingga upaya yang dibangun untuk mempersekutukan hubungan antargereja melalui persekutuan bersama antardenominasi gereja kurang mendapat dukungan dari semua gereja lokal di Doyo Sentani.Sistem pelayanan yang diterapkan gereja-gereja lokal masih bersifat tradisional atau yang sentri petal. Pelayanan gereja tidak secara luas dilakukan, melainkan hanya untuk kelompoknya sendiri, walaupun hal itu adalah sesuatu yang wajar, namun dalam kehidupan gereja kebersamaan itu merupakan unsur yang penting untuk dipertahankan sesuai dengan doa Tuhan Yesus dalam Yohanes 17 bahwa Yesus menghendaki agar semua orang percaya tetap bersatu.

Hal ini cenderung disebabkan gereja-gereja tidak menerima keberadaan gereja lain sebagai bagian integral dari tubuh Kristus yang am, karena hakikat gereja yang alkitabiah lebih kepada orang per orang yang percaya Tuhan Yesus Kristus, walaupun berbeda-beda denominasi gereja, tetapi satu tubuh dalam Kristus. Menurut Christian de Jonge dalam bukunya mengatakan, "Keesaan ini menjadi nyata dan tampak di mana saja orang yang dibaptis dalam nama Kristus dan yang mengakui Kristus sebagai Tuhan dikumpulkan oleh Roh Kudus untuk menjadi suatu persekutuan yang memegang iman rasuli yang satu, memberitakan Injil yang satu, memecahkan roti yang satu, berdoa bersama dan hidup bersama dalam pelayanan kepada segala manusia." 7

Barnabas Suebu mengatakan, bahwa hal yang sangat memprihatinkan untuk diwaspadai adalah posisi dan peranan generasi muda. Ia lahir di tengah-tengah perjalanan di antara dua peradaban. Ia tidak pernah berada dan mengalami langsung peradaban masyarakat yang lama, tetapi juga belum masuk sepenuhnya ke dalam peradaban masyarakat modern. Dalam kondisi seperti ini sangat mudah baginya untuk mengalami goncangan-goncangan jiwa bahkan frustrasi, hidup tanpa arah dan tujuan yang jelas. Dalam hubungan ini kita mengamati gejala-gejala degenerasi (kemerosotan generasi dari generasi sebelumnya) hal mana yang memengaruhi mutu kehidupan masyarakat dan mutu sumber daya manusia di masa depan. ${ }^{8}$ Pernyataan di atas

\footnotetext{
${ }^{7}$ Christiaan de Jonge, Menuju Keesaan Gereja (Jakarta: BPK Gunung Mulia, 2010), 138.

${ }^{8}$ Barnabas Suebu, "Injil dan Masyarakat Sentani," Ceramah: Disampaikan pada Sidang Klasis GKI Sentani. Ifale Tanggal 3-6 Nopember 1999, Sentani Jayapura Papua.
} 
memberikan gambaran yang jelas bahwa salah satu sisi negatif dari perubahan zaman baru bagi pertumbuhan gereja di Doyo Sentani ialah terjadinya kemerosotan moral generasi muda. Generasi muda dalam hal ini gagal meneruskan tongkat estafet kepemimpinan gereja dari generasi sebelumnya sehingga mereka frustrasi dan tidak memberikan teladan yang baik bagi generasi selanjutnya. Generasi di abad 21 ini lebih jahat dibandingkan dengan generasi sebelumnya, sehingga tokoh gereja, tokoh adat, tokoh pemerintah kampung mampu memberikan jawaban atas pergumulan ini sebagai solusi. Sebab generasi muda adalah penerus dalam kepemimpin kampung, gereja, masyarakat luas, bangsa, dan negara.

\section{Pokok Masalah}

Dari latar belakang masalah di atas, maka yang menjadi rumusan masalah adalah bagaimana pelayan jemaat, gembala sidang dan kaum awam memahami dengan benar pengaruh kerjasama persekutuan bersama antardenominasi dapat mengoptimalkan hubungan yang membawa perubahan dalam gereja-gereja lokal di Doyo Sentani?

\section{Tujuan Penelitian}

Penelitian ini dilaksanakan dengan tujuan adalah untuk mengetahui pengaruh kerjasama dalam persekutuan bersama antargereja dapat mengoptimalkan sesuatu yang berguna untuk mambawa perubahan dalam gereja-gereja lokal di Doyo Sentani.

\section{Manfaat Penelitian}

Setelah melakukan penelitian, diharapkan akan ada kegunaan bagi kepentingan-kepentingan sebagai berikut:

Pertama, Bagi Ilmu Teologi: memberi sumbangsih kepada teologi sistematis, khususnya dalam bidang ekklesiologi berupa kajian teori tentang hakikat gereja yang benar dan alkitabiah.

Kedua, Bagi Lembaga Gereja: secara praktis hasil penelitian ini, dapat membuka wawasan para pemimpin gereja tentang keuntungan dari persekutuan bersama antargereja di Doyo Sentani dan dapat menjadi pendorong para pelayan jemaat dan gembala sidang untuk melaksanakan prinsip-prinsip firman Tuhan tentang hakikat gereja secara benar.

\section{Kesatuan Orang Percaya}

\section{Yesus Menghendaki Kesatuan Orang Percaya}

Kesatuan orang percaya merupakan kebenaran yang hakiki yang Yesus ajarkan. Dengan kata lain kesatuan adalah prinsip yang mutlak benar bagi semua orang yang sudah dilahirkan kembali oleh Roh Kudus. 
Hal ini tidak bisa ditolak keabsahannya oleh berbagai organisasi gereja dalam dunia ini, yang mengerti kehendak Allah. J. Wesley Brill mengatakan bahwa persatuan itu adalah persatuan antara semua orang yang ada di dalam Kristus dan Kristus di dalam mereka. Persatuan antara semua orang yang sudah dilahirkan kembali oleh Roh Kudus menjadikan kita saudara dalam satu keluarga. Roh Kudus mempersatukan kita kepada Kristus dan kita sungguh-sunngguh dipersatukan, walaupun kita semua tidak berada dalam lingkungan gereja yang sama. Rasul Paulus berkata mengenai "memelihara kesatuan Roh" (Efesus 4:3,13). Persatuan yang didoakan Yesus untuk kita adalah persatuan yang sama dengan persatuan Yesus dan Bapa-Nya, "supaya mereka semua menjadi satu... di dalam kita" (17:21). ${ }^{3}$ Dari pernyataan di atas dapat disimpulkan bahwa kesatuan orang percaya adalah kehendak Allah dan eksistensinya patut dipertahankan oleh gereja pada masa kini.

Tuhan mengatakan, "Supaya semua menjadi satu" (Yohanes 17:2la). Ungkapan ini mengandung makna yang sangat penting untuk dipahami antara lain: Pertama, manusia sebagai gambar dan rupa Allah hubungannya terjalin kembali seperti pada waktu Allah menciptakan manusia. Ada persekutuan yang erat antara manusia dengan Allah melalui pengorbanan Tuhan Yesus Kristus di kayu salib. Kedua, Tuhan Yesus tidak menghendaki perpecahan diantara orang percaya karena Yesus sudah mendamaikan manusia dengan Allah melalui kematiannNya di Golgota. Walter Mohr mengatakan, "Semua jemaat Kristus di seluruh dunia adalah tubuh-Nya dan tubuh Kristus atau jemaat itu sebenarnya hanya satu."

Kebenaran tentang kesatuan orang percaya atau gereja seperti yang dikatakan oleh Tuhan Yesus dalam Injil Yohanes 17:20-23, menyatakan bahwa kesatuan orang percaya itu sama seperti kesatuan antara Anak dan Bapa-Nya. Ini berarti bahwa kesatuan orang percaya atau gereja, sesungguhnya merupakan suatu kesatuan yang sangat sempurna, meskipun tetap ada keanekaragaman dalam organisasi gereja. Yusuf Roni dalam bukunya mengatakan, "Kesatuan itu secara esensial adalah kesatuan yang mutlak harus dimiliki oleh setiap orang percaya."

Gereja dalam pengertian sebenarnya adalah tubuh Kristus. Tubuh itu terdiri atas banyak anggota, tetapi satu kepala, yaitu Yesus Kristus. Gereja disebut sebagai tubuh Kristus berarti menunjuk kepada orangnya, bukan gereja dalam arti organisasi yang nyata. Walter Mohr mengatakan, "Jemaat bukan gedung gereja, bukan organaisasi, bukan

\footnotetext{
${ }^{3}$ J. Wesley Brill, Tafsiran Injil Yohanes (Bandung: Kalam Hidup, 1995), 172.

${ }^{4}$ Walter Mohr, Anda Dan Gereja (Surabaya: YAKIN, n.d), 16.

${ }^{5}$ Yusuf Roni, Berbicara tentang Kesatuan Gereja (Yogyakarta: Yayasan ANDI, 1993), 
sistem, melainkan organisme yang hidup." ${ }^{6}$ Organisasi gereja yang beraneka ragam dalam dunia ini merupakan satu kesatuan yang utuh dan tidak terpisahkan antara satu dengan yang lain, karena semua orang percaya sudah dipersatukan oleh Yesus Kristus di hadapan Allah melalui kematian dan kebangkitan-Nya. Itu sebabnya gereja disebut tubuh Kristus yang di dalamnya banyak anggota tubuh, tetapi kepalanya satu, yaitu Yesus Kristus.

\section{Langkah-Langkah Optimalisasi Hubungan Antar-Gereja}

Langkah-langkah yang ditempuh dalam bagian ini merupakan praktisasi dari optimalnya hubungan antargereja yang diharapkan. Ada tiga pendekatan yang diupayakan atau dilakukan dalam langkah optimalisasi, yaitu pendekatan dengan pemimpin gereja, pertemuan dengan para pemimpin gereja, dan mengadakan rapat bersama guna membicarakan langkah-langkah hubungan kerjasama pelayanan dan kepentingan bagi pertumbuhan gereja lokal diwujudkan dalam tindakan nyata. Menurut Ted W. Engstrom \& Edward R. Dayton, "Sangatlah perlu diingat bahwa setiap langkah dari rencana tersebut sebenarnya merupakan suatu sasaran. Karena itu, setiap langkah harus mempunyai karakteristik yang sama dengan sasaran akhir dari proyek tersebut: setiap langkah haruslah dapat dicapai dan diukur."'

\section{Pendekatan Pemimpin Gereja}

Langkah pertama dalam upaya optimalisasi hubungan antargereja adalah mengadakan pendekatan kepada para pemimpin gereja (gembala atau pelayan jemaat) dari semua gereja lokal, guna membicarakan kepentingan dari hubungan antargereja bagi pertumbuhan gereja lokal dari semua denominasi. Dalam langkah pendekatan ini, ada hal penting yang perlu disosialisasikan.

\section{Pertemuan dengan Para Pemimpin Gereja}

Pertemuan dengan para pemimpin gereja diprioritaskan supaya nantinya mereka akan menjadi mediator bagi anggota jemaat untuk menyampaikan visi dan misi serta keuntungan dari hubungan antargereja dalam kaitannya dengan persekutuan bersama agar menjadi visi dan misi bersama gereja. Hal ini penting, karena sekaligus menjadi tolok ukur atau landasan bagi langkah selanjutnya. Pendekatan ini merupakan langkah efektif dalam mewujudkan hubungan kerjasama pelayanan antargereja, karena mereka memiliki pengaruh yang sangat

\footnotetext{
${ }^{6}$ Yusuf Roni, Berbicara tentang Kesatuan Gereja , 16.

${ }^{7}$ Ted W. Engstrom \& Edward R. Dayton, Seni Manajemen bagi Pemimpin Kristen (Bandung: Kalam Hidup, 2007), 41.
} 
besar dalam gereja lokal. Selama ini hal tersebut tidak diperhatikan dengan baik oleh gereja lokal yang mempunyai gagasan ini, sehingga hubungan antargereja tidak berjalan dalam satu kerangka yang formal seperti yang diharapkan. Dengan dilakukannya pendekatan ini, ada peluang yang terbuka untuk bekerjasama itu dapat berjalan. Yakob Tomatala yang mengutip pernyataan J. Robert Clinton mengatakan, "Pemimpin Kristen adalah seseorang yang telah dipanggil Allah sebagai 'Pemimpin' yang ditandai oleh kapasitas memimpin dan tanggung jawab pemberian Allah untuk memimpin suatu kelompok umat Allah (gereja) mencapai tujuannya bagi serta melalui kelompok ini."

Para pemimpin gereja adalah penentu dalam pengambilan keputusan karena mereka adalah pemimpin sebab secara organisasi mereka mempunyai wewenang penuh dalam memutuskan dan melaksanakan keputuasan tersebut. Yakob Tomatala mengatakan, "Mengambil keputusan adalah proses dimana seorang pemimpin menentukan sebelumnya kebijaksanaan yang akan diambil dan dijalankan untuk mencapai tujuan organisatoris."

\section{Rapat Bersama}

Untuk melakukan suatu pekerjaan besar seperti hal memulai dan melaksanakan kerjasama pelayanan antargereja perlu ada rapat bersama. Rapat bersama ini dimaksud untuk membahas cara kerja dan hasil apa yang akan dicapai. Rencana pelayanan dapat dibicarakan dalam rapat bersama ini, tetapi rapat bersama hanya sebatas alat. Yakub B. Susabda mengatakan, "Rapat hanyalah alat yang dipilih dan dipakai oleh gereja dengan sengaja untuk membantu kehidupan dan pelayanannya. Oleh karena itu, selama peraturan-peraturan gereja mengenairapat atau persidangan ini tidak bertentangan dengan kebenaran Firman Tuhan, kita harus bisa mempergunakannya dengan penuh tanggungjawab."10

Orang-orang yang diundang adalah para pemimpin gereja (gembala sidang dan pelayan jemaat), ketua-ketua komisi dan kaum awam dari setiap gereja lokal. Rapat bersama ini akan menjadi kerangka acuan untuk menciptakan relasi formal antargereja yang diwujudkan melalui kerjasama pelayanan antar gereja-gereja lokal.

\footnotetext{
${ }^{10}$ Yakub B. Susabda, Prinsip-Prinsip Pertimbangan Utama Administrasi Gereja (Malang: Gandum Mas, 1981), 73.
} 1993), 59.

${ }^{8}$ Yakob Tomatala, Kepemimpinanyang Dinamis (Malang: Gandum Mas, 2005), 45.

${ }^{9}$ Ibid., Penatalayanan Gereja yang Efektif di Dunia Modern (Malang:Gandum Mas, 
Materi rapat bersama ini menyangkut semua sistem pelayanan yang mau diterapkan, dibahas dan disetujui bersama. Hasil rapat ini akan dijadikan sebagai panduan atau pedoman dalam pelaksanaan persekutuan bersama antargereja lokal.

Keputusan yang diambil dalam rapat bersama ini adalah keputusan semua gereja lokal dan semua gereja lokal wajib melaksanakannya. Untuk mensosialisasikan keputusan-keputusan itu, maka dalam rapat bersama ini dipilih badanpengurus yang khusus untuk menangani semua urusan yang berkenaan dengan kerjasama pelayanan persekutuan antargereja lokaluntuk dapat mengurus semua jadwal kegiatan yang ditetapkan bersama supaya apa yang diprogramkan dapat dikawal dengan baik.

\section{Memilih Badan Pengurus Khusus}

Memilih badan pengurus ini sangat penting supaya mereka dapat menangani pelayanan secara full time, baik pelayanan intern ke dalam maupun ekstern ke luar. Orang-orang yang dipilih untuk duduk dalam kepengurusan ini adalah wakil dari semua gerejalokal dengan tujuan untuk menyatakan atau membuktikan bahwa wadah kerjasama pelayanan antargereja adalah milik bersama. Berarti gereja lokal lainpun secara tidak langsung mempunyai andil untuk membina anggota jemaat dari gereja lokal yang lain. Badan terpilih ini secara resmi dapat memimpin dan mengatur sistem pelayanan, baik pelayanan rohani maupun pelayanan sosial.

\section{Membentuk Persekutuan Formal Antargereja}

Pembentukan persekutuan formal antargereja merupakan langkah konkret yang patut ditanggapi serius oleh semua gereja lokal, selama ini persekutuan antargereja tidak formal. Dengan terbentuknya wadah formal ini berarti secara resmi persekutuan bersama antargereja mempunyai kekuatan hukum yang tidak dapat dibatalkan oleh sekelompok orangkarena kesepakatan ini adalah inisiatif semua gereja. Apapun yang akan terjadi dikemudian hari (artinya terjadi perbedaan persepsi) gereja-gereja lokal turut bertanggungjawab atas program bersama ini. Inilah manfaat dari pembentukan persekutuan formal antargereja lokal yang disetujui oleh semua gereja.

Pembentukan persekutuan formal antargereja lokal itu sangat penting karena memiliki andil yang besar untuk mengantisipasi semua kemungkinan yang timbul, seperti problem atau masalah-masalah yang sering terjadi di dalam kehidupan bergereja yang disebabkan kurangnya relasi formal antargereja sehingga timbul banyak salah tafsir yang sering berdampak pada lemahnya hubungan antargereja. 
Pengaruh persekutuan formal antargereja sangat besar, karena gereja lokal dapat berpartisipasi melalui wadah kebersamaan ini untuk meredamkan ketegangan-ketegangan perbedaan pendapat di dalam dan antargerej-gereja lokal dan memberantas segala bentuk kejahatanserta dapat mempererat tali persaudaraan yang rukun dan

damai diantara sesama orang percaya.

\section{Membuat Program}

Sangat perlu adanya program yang jelas dalam organisasi apapun. Dalam menyusun dan mencanangkan suatu program perlu memerhatikan aspek daya dan dana supaya tujuan akhir dapat diukur berdasarkan kemampuan yang ada sehingga program kerja tersebut tidak mengambang jauh dari yang diharapkan untuk dicapai oleh gereja lokal. Yakob Tomatala mengatakan, "Program kerja atau program pencapaian tujuan mencakup rancangan yang berhubungan dengan pelaksanaan tugas. Hal ini menjelaskan langkah-langkah penting yang digariskan untuk tugas-tugas dan pelaksanaan tugas, sehingga semua kegiatan organisatoris berjalan secara terpadu ke target." "ll

Tujuan dari penyusunan program kerja adalah menemukan kebutuhan-kebutuhan dan berusaha untuk memenuhinya. Dalam bagian ini langkah yang perlu dipikirkan adalah menentukan kebutuhan, menentukan tujuan, menetapkan tema, menetapkan liturgi, menetapkan aktivitas. Semua ini bertumpu pada tujuan yang hendak dicapai melalui persekutuan bersama antargereja-gereja lokal.

\section{Menentukan Kebutuhan}

Menentukan kebutuhan berarti melihat persoalan gereja dan hasil yang akan dicapai. Berkaitan dengan persekutuan antargereja, kebutuhan yang hendak dicapai adalah memenangkan jiwa-jiwa baru dan mengaktifkan anggota jemaat yang tidak aktif menjadi aktif dan bertannggungjawab bagi Kristus melalui gereja atau organisasinya.

Untuk memenuhi kebutuhan gereja-gereja lokal dalam hal meningkatkan mutu rohani, perlu ada komitmen bersama tentang kerjasama dari semua komponen atau unsur yang ada dalam gereja lokal guna menjalankan program-program yang sudah ditetapkan bersama dengan badan kerjasama pelayanan persekutuan bersama antargereja sehingga mencapai sasaran atau target dengan berdasarkan upaya yang maksimal. Sasaran dari menentukan kebutuhan adalah hasil yang diakibatkan terpenuhinya kebutuhan gereja-gereja lokal dari kondisi statis menjadi stabil kembali, yaitu karena meningkatnya pertumbuhan

\footnotetext{
${ }^{11}$ Yakob Tomatala, Penatalayanan Gereja yang Efektif di Dunia Modern (Malang: Gandum Mas, 1993), 56.
} 
rohani anggota jemaat sebagai ukuran dari pertumbuhan secara kualitas, kuantitas, dan organik. Secara umum orang merasa puas jika kebutuhannya terpenuhi semua, walaupun hal itu sangat relatif bagi semua orang. Itu sebabnya badan kerjasama pelayanan antargerejagereja lokalseharusnya jeli melihat kebutuhan anggota jemaat dari berbagai aspek, baik latar belakang sosial budaya, tingkat pendidikanmaupun perilaku seseorang dan lain sebagainya supaya apa yang diprogramkan menyentuh semua lapisan masyarakat secara menyeluruh tanpa terkecuali agar kebutuhan rohani tiap-tiap orang terpehuhi.

\section{Menentukan Visi dan Misi}

Menentukan visi dan misi dalam sebuah perkumpulan adalah penting karena visi dan misi itu menjadi tolok ukur sebuah usaha pemimpin dan bawahan dalam mencapai tujuan. Organisasi atau perkumpulan apa saja perlu menajamkan pikiran dengan baik untuk mencapai tujuan. Karena itu, diperlukan visi dan misi yang jelas. Menurut Kamus Besar Bahasa Indonesia visi adalah "Kemampuan untuk melihat atau mengetahui sampai pada inti atau pokok dari suatu hal atau persoalan". ${ }^{12}$ Visi dan misi yang jelas dapat membawa suatu organisasi mencapai tujuan yang diharapkan. Menurut Daniel Ronda, "Pertama, visi adalah gambar pikiran yang jelas yang memimpin kita untuk meraih masa depan. Kedua, visi melihat sesuatu yang belum ada di sini dan hari ini-memvisualisasikan sesuatu sebelum itu terjadi. Ketiga, oleh kuasa Roh Kudus, Allah memberikan visi kepada pemimpin Kristen untuk menuntun pada sesuatu yang belum ada di dini pada hari ini." ${ }^{.13}$

\section{Menentukan Tujuan}

Dalam pelakasanaan suatu program perlu menentukan tujuan yang jelas untuk dicapai. Kalau program yang dicanangkan itu tujuannya tidak jelas tentu program tersebut menganmbang tanpa arah dan tujuan yang jelas. Yakob Tomatala mengatakan, "Menetapkan tujuan ialah menentukan hasil yang diharapkan untuk dicapai, sebagai dasar untuk melaksanakan segala tugas ke arah pencapaian hasil itu." ${ }^{14}$ Menentukan tujuan berarti menstimulasi badan kerjasama pelayanan dan gereja lokal untuk berpartisipasi sesuai program untuk mencapai hasil yang

\footnotetext{
2007), 1356.

${ }^{13}$ Daniel Ronda, Leadership Wisdom Antologi Hikmat Kepemimpinan (Bandung: Kalam Hidup, 2011), 16.

${ }^{14}$ Yakob Tomatala, Penatalayanan Gereja yang Efektif di Dunia Modern (Malang: Gandum Mas, 1993), 55.
}

${ }^{12}$ W.J.S. Poerwadarminta, Kamus Besar Bahasa Indonesia (Balai Pustaka Jakarta, 
diharapkan bersama. Peluang untuk pertumbuhan gereja-gerejalokal sangat terbuka apabila program kerja pelayanan persekutuan bersama antargereja dapat dilaksanakan secara terpadu supaya mencapai hasil yang maksimal seperti yang diharapkan. Tujuannya ialah mengarahkan pandangan pada upaya bersama gereja mencapai target. Y. Tomatala mengatakan, "Fungsi tujuan ialah membimbing dan mengarahkan kepada suatu tujuan (target) yang akan dicapai." ${ }^{15}$ Hasil akan dicapai apabila tujuannya jelas dan gereja lokal bekerjasama melakukan pekerjaan Tuhan.

\section{Menetapkan Tema}

Ibadah yang sifatnya antar denominasi seharusnya menetapkan tema karena disamping menghindari khotbah-khotbah yang ekstrim, denominasi juga merupakan salah satu faktor penunjang mencapai tujuan akhir, yaitu pertumbuhan dari gereja-gereja lokal. Tujuan menetapkan tema dalam semua kegiatan rohani ialah supaya ajaran firman Tuhan yang diajarkan itu teratur dan terarah kepada sasaran yang hendak dicapai agar anggota jemaat dituntun kepada pemahaman Alkitab atau firman Allah yang lebih mendalam danakibatnya menghasilkan buah-buah kebenaran yang dikerjakan oleh Roh Kudus dalam kehidupan anggota jemaat sehingga bertumbuh.

Tema yang ditetapkan menyangkut tema umum dan tema khusus. Tema umum semuanya mengarah kepada upaya pertumbuhan dari gereja-gereja lokal dengan sistem pelayanan tepatguna dan berhasilguna. Tema ini sifatnya fleksibel atau temporer, tidak paten dan dapat disesuaikan dengan kebutuhan anggota jemaat yang ada pada saat itu.

\section{Menetapkan Liturgi}

Salah satu kendala dalam persekutuan bersama antargereja yang sering muncul dan kompleks sekali adalah masalah liturgi dari berbagai denominasi gereja. Tata cara penyembahan gereja lokal yang berbedabeda sangat rentan dan menjadi jurang antara satu denominasi dengan denominasi lain. Hal ini adalah ciri khas tiap-tiap gereja lokal yang tidak dapat dipungkiri. Solusi yang diberikan adalah dengan menetapkan sistem liturgi yang sesuai keinginan semua gereja akan menolong badan kerjasama untuk melaksanakan tugasnya dengan tidak ragu-ragu dan juga semua anggota jemaat dari berbagai denominasi gereja yang ada dapat beribadah tanpa ada rasa asing dengan liturgi yang ditetapkannya untuk diikuti dalam ibadah bersama antargereja-gereja lokal yang ada.

\footnotetext{
${ }^{15}$ Ibid, 56
} 
Memang diakui bahwa liturgi dan tata cara penyembahan model apapun kapasitasnya hanya sebagai sarana yang melaluinya Tuhan memberkati umat-Nya. Ibadah yang sifatnya semangat atau tidakdan liturgi yang lebih baik daripada yang lain bukanlah merupakan ukuran mutlak tanda kehadiran Allah, melainkan penyerahan hati secara total kepada Tuhan lewat penyembahan itu yang terpenting dan berkenan kepada Allah karena itulah yang Tuhan kehendaki dari orang percaya, bukan liturginya.

\section{Menetapkan Aktivitas}

Aktivitas yang dilakukan lewat persekutuan bersama antargereja mencakup dua bidang pelayanan, yaitu bidang pelayanan rohani dan bidang pelayanan sosial, antara lain:

Kegiatan rohani menyangkut persekutuan bersama, seperti pelayanan tukar mimbar (khotbah), pelayanan perkunjungan pastoral, penginjilan, kebaktian kebangunan rohani (KKR), pelayanan tim konseling dan seminar yang ditetapkan bersama.

Aktivitas pelayanan rohani dilaksanakan sesuai dengan kebutuhan anggota jemaat. Apapun jenis pelayanan tujuannya mengarah kepada target, yaitu hasil yang diharapkan untuk dicapai melalui persekutuan bersama antargereja adalah peningkatan kualitas iman anggota jemaat. Bila kualitas iman anggota jemaat bertumbuh berarti gereja lokal juga ikut bertumbuh karena adanya orang-orang percaya yang mengerti kehendak Tuhan. Eddy Paimoen mengatakan bahwa tugas pertama, koinonia memelihara persekutuan umat dengan tujuan peningkatan iman dan pengabdian kepada Yesus. Tugas pertama ini, memberikan kemungkinan dankesempatan yang seluas-luasnya kepada warga gereja untuk berperan serta secara aktif sesuai dengan karunia dan talenta dan karunia yang dimiliki.Tugas gereja adalah menggali dan mengembangkan karunia agar dapat didayagunakanuntuk pelayanan tubuh Kristus. Gereja sedapat mungkin memperjuangkan persekutuan dan persatuan umat Kristen, baik secara denominasional maupun interdenominasi. ${ }^{16}$

Kegiatan sosial mencakup kerja bakti bersama, arisan antargereja, membantu janda-janda miskin, pertandingan persahabatan (olehraga) antargereja, membantu pekerjaan Tuhan melalui dana, dan lain sebagainya.Aktivitas pelayanan sosial bertujuan untuk saling menolong, saling melengkapi serta meningkatkan rasa persaudaraan yang lebih mendalam oleh kasih yang mengalir dari Allah.

\footnotetext{
${ }^{16}$ Eddy Paimoen, Kerajaan Allah dan Gereja (Banadung: Agiamedia, 1999), 61.
} 


\section{Menandatangani Surat Persetujuan}

Sifat kerjasama pelayanan antargereja ini tentu tidak terlepas dari masalah-masalah, baik internal maupun eksternal serta dampak negatif yang timbul dari persekutuan bersama antargereja yang mungkin disebabkan oleh perbedaan persepsi, cara pandang dan penafsiran yang berbeda. Untuk menghindari bahaya disintegrasi dalam persekutuan bersama perlu ada surat persetujuan yang isinya menyangkut pernyataan-pernyataan penting. Di dalam surat persetujuan bersama ini tertuang garis besar dari semua keputusan dan peraturan yang berhubungan dengan kegiatan kerjasama pelayanan antargereja. Tujuannya ialah sebagai tanda bukti bahwa kerjasama pelayanan antargereja sudah mendapat legitimasi dari semua pihak atau gereja lokal untuk mengawal bersama-sama agar tidak terjadi penyimpangan yang merugikan gereja lain.

Surat persetujuan atau pernyataan ini akan ditandatangani oleh semua gembala atau pelayan jemaat dengan membubuhi cap gereja masing-masing serta tembusan kepada badan pengurus daerah atau klasis atau wilayah atau sinode dari tiap-tiap gereja lokal yang ada sebagai barang bukti bahwa persekutuan bersama antargereja merupakan persetujuan dari semua perwakilan gereja yang ada.

Visi dan misi dari persekutuan bersama antargereja-gereja lokal adalah meningkatkan mutu rohani jemaat melalui semua upaya pembinaan rohani yang dilakukan badan kerjasama dan para gembala sidang dan pelayan jemaat. Arti visi menurut Yakob Tomatala, "Visi juga menjelaskan tentang kemampuan untuk melihat apa yang telah ditulis oleh Allah di dalam batin setiap orang tersebut. Visi yang diberikan oleh Allah ini memiliki tujuan yang pasti, yaitu untuk pemenuhan hidup, baik kehidupan individu, rumah tangga maupun kelompok dan kepemimpinan." 17

Pada hakikatnya dalam hal hubungan kerjasama pelayanan antargereja yang diupayakan secara bersama ini tidak menghendaki hal tersebut karena hal itu bukanlah tujuan utama. Kalaupun hal itu terjadi akan diproses berdasarkan anggaran dasar dan anggaran rumah tangga gereja yang bersangkutan serta penyelesaian yang arif dan bijaksana, supaya tidak menimbulkan konflik antargereja karena hal ini berpeluang untuk menghambat gerakan atau upaya optimalisasi hubungan antargereja.

${ }^{17}$ Yakob Tomatala, Anda Juha Bisa Menjadi Pemimpin Visioner (Jakarta: YT Leadership Foundation, 2005), 23. 


\section{METODOLOGI PENELITIAN}

\section{Jenis Penelitian}

Penelitian ini jenis penelitian yang peneliti pakai adalah jenispenelitian kuantitatif. Penelitian ini adalah penelitian yang mengambil sampel dari suatu populasi dan menggunakan kuesioner sebagai alat pengumpulan data yang pokok. ${ }^{18}$ Sesuai dengan tujuan penelitian ini, yaitu untuk mengetahui pemahaman pelayan jemaat, gembala sidang dan kaum awam mengenai persekutuan antar gereja di Doyo Sentani dan bagaimana pengaruhnya bagi optimalisasi pertumbuhan gereja di Doyo Sentani.

\section{Populasi dan Sampel \\ Populasi}

Populasi penelitian ini merupakan jumlah individu yang pasti, meliputi semua gereja dalam lingkup Doyo Sentani, yaitu sejumlah tujuh denominasi dan sembilan gereja.

\section{Sampel}

Sampel diambil dari populasi yang ada, dengan teknik 'purposif sampling', yaitu yang ditarik dengan sengaja (nonrandom) karena alasan yang jelas dan pasti yang telah diketahui dari populasi. Curry menyebutkan, bahwa jika populasi sampai dengan 100, maka sampel $100 \%$; jika populasi $100-1.000$, maka sampel $10 \%$; jika populasi di atas 1.000-5.000, maka sampel 5\%; jika populasi di atas 5.000-10.000, maka sampel 3\%; jika populasi di atas 10.000 maka sampel 1\%. Sedangkan Gay memberi pedoman yang lebih umum, yaitu 10\% sampel untuk populasi yang besar dan $20 \%$ sampel untuk populasi kecil. ${ }^{19}$

Peneliti memilih untuk menentukan besaran sampel berdasarkan pandangan Curry, yaitu 5\% untuk jumlah 1000-5000, sehingga besaran sampel yang diperoleh dari populasi sebanyak 2000 orang adalah sejumlah 100 orang dari tujuh denominasi gereja di Doyo Sentani.

\section{Teknik Pengumpulan Data}

Teknik pengumpulan data perlu dilaksanakan dengan baik. Teknik pengumpulan data dimulai dengan merumuskan informasi yang hendak dikumpulkan ke dalam bentuk pertanyaan atau angket.

\footnotetext{
${ }^{18}$ Masri Singarimbun dan Sofyan Effendi, Metode Penelitian Survei (Jakarta: LLP3ES, 1989),3.

${ }^{19}$ Ibid., 225.
} 


\section{Alat Pengumpul Data}

Alat pengumpul data utama dalam penelitian ini adalah kuesioner. Kuesioner diharapkan dapat memberikan masukan yang tepat dan cukup dalam menjawab pertanyaan-pertanyaan penelitian. "Kuesioner atau angket adalah penyelidikan mengenai suatu masalah yang menyangkut kepentingan orang banyak dengan cara mengedarkan formulir daftar pertanyaan., ${ }^{20}$

Berdasarkan pertanyaan penelitian, maka disusunlah daftar pertanyaan ke dalam bentuk kuesioner. Kuesioner dibuat dalam bentuk 12 butir item pertanyaan. Pokok penelitian dijabarkan ke dalam beberapa indikator. Dengan demikian, setiap pokok dan indikatornya akan terlihat seperti berikut:

Pertama, pemahaman para gembala sidang, pelayan jemaat dan kaum awam di Doyo Sentani tentang hakikat gereja, dengan indikatorindikator: (1) Paham para gembala dan pelayan jemaat tentang pengertian hubungan antargereja secara alkitabiah. (2) Paham tentang kerjasama antargereja di Doyo Sentani. Paham bahwa pada tingkat jemaat perlu ada pemahaman yang sama sebagai upaya menciptakan hubungan antargereja yang lebih optimal. (3) Paham tentang perlunya pembentukan persekutuan antar gereja secara formal. Paham bahwa pembentukan persekutuan secara formal sebagai bentuk kerjasama antargereja yang saling mengikat untuk dapat masing-masing menginplementasikan kesepakatan bersama. (4) Hubungan kerjasama antargereja.Gembala sidang dan pelayan paham bahwa terdapat keuntungan dalam bekerjasama dengan jemaat lain demi pertumbuhan gereja lokal.

Kedua, pelaksanaan optimalisasi hubungan antargereja secara konsisten dalam gereja lokal di Doyo Sentani dalam meningkatkan pertumbuhan gereja lokal. Indikator-indikatornya adalah sebagai berikut: (1) Adanya hubungan kerjasama antargereja secara rutin dan formal. (2) Pemimpin dan umat membangun penilaian yang positif terhadap doktrin gereja lain. (3) Pemimpin dan umat terlibat aktif dalam kerjasama antargereja di Doyo Sentani.

Adapun jawaban responden melalui angket ini menggunakan skala Likert, yaitu metode sederhana yang terdiri atas tiga kategori jawaban: setuju, ragu-ragu, tidak setuju. Tiap-tiap responden diasosiasikan dengan satu nilai, yang setiap nilai individu ditentukan dengan menjumlahkan nilai setiap pernyataan. ${ }^{21}$ Penjabarannya adalah sebagai berikut: penilaian atas jawaban responden dibagi ke dalam 3 kategori yaitu untuk nilai positif dimulai dengan setuju $=2$, ragu-ragu $=1$, tidak

\footnotetext{
${ }^{20}$ Kartini Kartono, Pengantar Metodologi Riset (Bandung: Mandar Maju, 1990), 127

${ }^{21}$ Sumanto, 45.
} 
setuju $=0$. Jawaban responden perlu diberi penilaian. Penilaian kategori dibagi ke dalam 4 kategori, yaitu buruk, kurang baik, baik dan sangat baik.Untuk itu, perlu dibuat interval bagi setiap kategori. Menentukan interval adalah dengan menggunakan rumus sebagai berikut:

Nilai kategori $=$ Jumlah responden $\mathrm{x}$ nilai tertinggi Jumlah kategori

Dengan membuat interval seperti tersebut di atas, maka setiap pertanyaan dapat dikategorikan ke dalam kategori tertentu sesuai dengan hasil yang didapatkan. Rumus ini akan berlaku, baik untuk pemahaman maupun pelaksanaan oleh responden terhadap optimalisasi hubungan antargereja di Doyo Sentani. Untuk menentukan validnya sebuah kuesioner, perlu dilakukan uji validitas.Validitas adalah suatu ukuran seberapa tepat teknik pengumpulan data melakukan fungsi ukurnya. ${ }^{22}$ Tujuan utamanya adalah untuk memastikan apakah isi kuesioner cukup dipahami oleh semua responden, dengan indikator kecilnya jawaban responden yang menyimpang dari rata-rata jawaban responden.

\section{Interpretasi Data}

Setelah data disajikan, langkah berikutnya adalah membuat interpretasi data sesuai dengan rancangan penelitian, sehingga dapat menjawab apa yang menjadi pertanyaan dalam penelitian ini.

Untuk menemukan makna dari penelitian yang disajikan, dibuatlah sebuah kesimpulan. Kesimpulan ini tentu berdasarkan teori dan tinjauan kepustakaan yang ada. Penyajian hasil penafsiran atau penemuan dalam penelitan kuantitatif ini dapat dilakukan dalam bentuk pembahasan atau dengan menggunakan cara lain.

\section{ANALISIS HASIL PENELITIAN DAN PEMBAHASAN}

Karakteristik Responden Secara Umum Berdasarkan Sampel

Tabel 1. Karakteristik Responden Secara Umum Berdasarkan Sampel

\begin{tabular}{|c|c|c|}
\hline Jenis Kelamin & Jawaban & Persentase \\
\hline Laki-laki & 57 & $57 \%$ \\
Wanita & 43 & $43 \%$ \\
\hline \multicolumn{3}{|c|}{ Status Perkawinan } \\
\hline Menikah & 78 & $78 \%$ \\
\hline
\end{tabular}

${ }^{22}$ Husaini Usman \& R. Purnomo Setiady A., Pengantar Statistika (Jakarta: Bumi Aksara, 2003), 291. 


\begin{tabular}{|c|c|c|}
\hline Tidakmenikah & 22 & $22 \%$ \\
\hline \multicolumn{3}{|c|}{ Usia Responden } \\
\hline 17 - 64 tahun & 100 & $100 \%$ \\
\hline Pendidikan & & $20 \%$ \\
SD & 20 & $7 \%$ \\
SMP & 7 & $57 \%$ \\
SMA & 57 & $16 \%$ \\
& 16 & \\
\hline
\end{tabular}

Dalam tabel 1 di atas, tampak karakteristik responden yang terlibat dalam penelitian ini. Dari 100 orang yang menjawab soal, 57 orang atau $57 \%$ adalah laki-laki, sedangkan 43 orang atau 43\% adalah wanita. Hal ini tidaklah mengherankan karena seorang wanita selalu menjadi nomor dua dalam kebudayaan orang timur dalam segala urusan.

Status pernikahan:78 orang atau 78\% menikah,sedangkan 22 orang atau 22\% tidak menikah. Usia responden 17-64 tahun.

Dalam hal pendidikan: 20 orang atau 20\% adalah setingkat SD, 7 orang atau $7 \%$ berpendidikan SMP dan 57 orang atau 57\% berpendidikanSMA, serta 16 orang atau 16\% setingkat Sl.

\section{Pemahaman Para Gembala, Pelayan dan Kaum Awam Tentang Hakikat Gereja yang Alkitabiah}

Hasil penelitian menunjukkan bahwa pemahaman para gembala sidang, pelayan jemaat dan kaum awam di Doyo Sentani tentang hakikat gereja yang alkitabiah dalam upaya membangun optimalisasi hubungan antargereja secara alkitabiah adalah 100 orang atau 100\% setuju dengan definisi hakikat gereja yang alkitabiah sebagai jembatan untuk membangun hubungan antargereja di Doyo Sentani menjadi optimal. Inimenunjukkan pemahaman yang sangat baik. Tidak ada yang raguragu. Pemahaman tentang kerjasama antargereja yang dikehendaki di Doyo Sentani ada 96 orang setuju (96\%) dengan pemahaman ini, 4 orang ragu-ragu (4\%). Mengenai perlu dibentuknya badan pengurus yang bersifat formal untuk mengatur kegiatan ibadah atau persekutuan antargereja, ada 89 orang setuju (89\%), sedangkan 6 orang ragu-ragu (6\%) dan 5 orang tidak setuju (5\%). Penekanan kepada perlunya persekutuan antargereja secara formal dapat diatur sedemikian rupa untuk menghindari perpecahan. Dalam hal ini ada beberapa poin penting untuk diperhatikan. Perlunya dilaksanakan persekutuan berasama secara rutin dan berkala, jawaban responden menunjukkan bahwa ada 94 orang setuju (94\%), 3 orang ragu-ragu (3\%), 3 orang tidak setuju (3\%). Adanya kebutuhan persekutuan antargereja seperti kebaktian bersama dapat meningkatkan keakraban dan pertumbuhan rohani, yaitu 
98 orang setuju (98\%), 2 orang ragu-ragu (2\%). Adanya hubungan antargereja secara rutin dan formal dengan pertanyaan Anda pernah menghadiri kegiatan yang dilaksanakan antargereja di Doyo Sentani, yaitu $87 \%$ menyatakan setuju, $8 \%$ menyatakan ragu-ragu, dan 5\% tidak setuju.

Pertanyaan tentang hal mengetahui adanya sebuah kegiatan rutin yang dilaksanakan oleh badan kerjasama antar gereja di Doyo Sentani, yaitu $87 \%$ menyatakan setuju, $10 \%$ ragu-ragu, dan 3\% tidak setuju. Dalam hal gereja di mana Anda tinggal menjalin hubungan dengan gereja lain dalam bentuk formal dan jawaban responden sangat jelas bahwa $83 \%$ menyatakan setuju, $14 \%$ ragu-ragu, dan 3\% tidak setuju.

\section{Pelaksanaan Optimalisasi Hubungan Antar-Gereja secara Konsisten dalam Gereja Lokal di Doyo Sentani}

Pokok kedua adalah pelaksanaan atau pelaksanaan adanya hubungan antargereja secara rutin dan formal. Penerapan merupakan kunci pelaksanaan sebuah teori. Betapapun baiknya sebuah teori ataupun peraturan, jika tidak diterapkan akan menjadi sia-sia belaka dan tidak berguna. Dalam hal ini, pelaksanaan hubungan antargereja yang mengarah kepada optimalisasi hubungan antargereja di Doyo Sentani dilakukan oleh para gembala sidang, pelayan dan kaum awam.

Adanya hubungan antargereja secara rutin dan formal dengan pertanyaan apakah Anda pernah menghadiri kegiatan yang dilaksanakan antargereja di Doyo Sentani, ternyata ada 87\% menyatakan setuju, 8 8\% ragu-ragu, dan 5\% tidak setuju. Dalam hal mengetahui adanya sebuah kegiatan rutin yang dilaksanakan oleh badan kerjasama antargereja di Doyo Sentani, ternyata ada 87\% menyatakan setuju, 10\% ragu-ragu, dan $3 \%$ tidak setuju. Dalam hal gereja di mana Anda tinggal menjalin hubungan dengan gereja lain dalam bentuk formal dan jawaban responden sangat jelas bahwa 83 orang atau $83 \%$ setuju, 14 orang atau $14 \%$ ragu-ragu, 3 orang atau 3\% tidak setuju.

Pelaksanaan yang perlu diperhatikan berikutnya adalah tentang pemahaman para pemimpin dan umat dalam membangun penilaian yang positif terhadap doktrin gereja lain. Dalam anggapan bahwa terdapat doktrin yang sehat pada gereja selain gereja lokal, jawaban responden adalah ada $80 \%$ menyatakan setuju, 16\% yang ragu-ragu, dan $4 \%$ tidak setuju. Peneliti juga mencoba menanyakan bahwa pernahkah Anda mendapat berkat rohani ketika mendengarkan khotbah dari gereja yang bukan denominasi anda, responden menjawab: ada 90\% menyatakan setuju, $7 \%$ ragu-ragu, dan 3\% tidak setuju.

Pemimpin dan umat terlibat aktif dalam kerjasama antargereja, karena Anda atau pemimpin gereja Anda pernah terlibat dalam kegiatan antargereja di Doyo Sentani, jawaban responden adalah 86\% menyatakan 
setuju, $6 \%$ ragu-ragu, dan $8 \%$ tidak setuju. Anda mengenal dengan baik beberapa orang dari gereja lain selain gereja Anda, jawabannya: ada 92 orang atau $92 \%$ menyatakan setuju, 5 orang atau $5 \%$ yang ragu-ragu, dan 3 orang atau 3\% menyatakan tidak setuju.

\section{Pembahasan Data}

Penelitian ini dilakukan untuk melihat seberapa jauh pemahaman para gembala sidang, pelayan jemaat, dan kaum awam tentang optimalisasi hubungan antargereja di Doyo Sentani dan pelaksanaannya dilapangan.

Berdasarkan penyajian data yang telah dikemukakan di depan dapatlah dilihat beberapa hal. Baik tentang karakteristik responden maupun tentang pemahaman dan pelaksanaan para gembala sidang, pelayan jemaat dan kaum awam terhadap optimalisasi hubungan antargereja sebagai salah satu upaya untuk pertumbuhan gereja lokal di Doyo Sentani.

\section{Optimalisasi Hubungan Antargereja di Doyo Sentani}

Dalam upaya mengoptimalisasikan hubungan antargereja di Doyo Sentani menjadi hal penting karena kondisi umat Tuhan yang ada dalam gereja-gereja lokal mengalami degradasi moral yang berdampak pada pertumbuhan gereja, baik secara kualitas maupun secara kuantitas.

Gereja-gereja lokal di Doyo Sentani sangat memahami keadaan ini dan salah satu cara untuk mengatasi adalah membangun hubungan antar gereja, sehingga umat Tuhan dari berbagai denominasi yang ada dalam gereja lokal dapat tertolong. Karena setiap gereja mempunyai asas atau dogma yang sering menjadi pijakan itu berbeda dengan denominasi lain, maka ada langkah-langkah konkret yang dilakukan untuk mengoptimalisasikan hubungan antargereja lokal di Doyo Sentani, yaitu pendekatan kepada para pemimpin gereja dan adat, rapat bersama, membuat surat persetujuan pelaksanaan kegiatan dan evaluasi.

Langkah-langkah yang ditempuh dalam bagian ini merupakan praktisasi dari optimalnya hubungan antargereja di Doyo Sentani. Ada dua hal yang diupayakan dalam langkah optimalisasi, pendekatan pemimpin gereja dan rapat bersama, guna membicarakan langkahlangkah hubungan kerjasama pelayanan dan kepentingan bagi pertumbuhan gereja lokal di Doyo Sentani.

\section{Pendekatan Pemimpin Gereja}

Langkah pertama dalam upaya optimalisasi hubungan antargereja lokal di Doyo Sentani adalah mengadakan pendekatan kepada para pemimpin, baik mereka sebagai pemimpin gereja (gembala atau pelayan jemaat) dari semua gereja lokal dan pemimpin adat yang secara tidak 
langsung terikat dengan pemimpin adat guna membicarakan kepentingan dari hubungan antargereja bagi pertumbuhan gereja lokal di Doyo Sentani. Dalam langkah pendekatan ini, ada hal penting yang perlu disosialisasikan. Peneliti dan gereja-gereja lokal di Doyo yang mempunyai visi ini, yaitu Gereja Kemah Injil Indonesia, Gereja Pantekosta di Indonesia, Gereja Kristen Injili di Tanah Papua dan Gereja Advent berkenaan dengan optinalisasi hubungan antargereja dan sekaligus mengajak gereja-gereja lokal untuk turut berpartisipasi dalam mewujudkan visi dan misi tersebut. Persekutuan antargereja adalah realisasinya, bahwa mereka mendukung gagasan ini. Pertemuan dengan para pemimpin gereja diprioritaskan supaya nantinya mereka akan menjadi mediator bagi anggota jemaat untuk menyampaikan visi dan misi serta keuntungan dari hubungan antargereja dalam kaitannya dengan persekutuan bersama agar menjadi visi dan misi bersama gereja. Pendekatan ini merupakan langkah efektif dalam mewujudkan hubungan kerjasama pelayanan antargereja, karena mereka memiliki pengaruh yang sangat besar dalam gereja lokal. Selama ini, hal tersebut tidak diperhatikan dengan baik oleh gereja lokal yang mempunyai gagasan ini, sehingga hubungan antargereja di Doyo Sentani tidak berjalan dalam satu kerangka yang formal seperti yang diharapkan.

Dalam menciptakan optimalisasi hubungan antargereja di Doyo Sentani yang sekarang sudah berjalan dengan baik itu berkat kepedulian pemimpin adat (Ondoafi dan Kepala suku) yang memprakarsai ibadah bersama serta mengajak semua gereja lokal untuk bekerja sama membina masyarakat adatnya yang ada dalam gereja-gereja lokal. Para pemimpin gereja adalah penentu dalam pengambilan keputusan, karena mereka adalah pemimpin. Secara organisatoris mereka memunyai wewenang penuh dalam memutuskan dan melaksanakan keputuasan tersebut. Yakob Tomatala mengatakan, "Mengambil keputusan adalah proses dimana seorang pemimpin menentukan sebelumnya kebijakssanaan yang akan diambil dan dijalankan untuk mencapai tujuan organisatoris." ${ }^{23}$ Pendekatan kepada para pemimpin gereja sudah berhasil karena ada respon positif, yaitu dengan adanya dukungan dari mereka, maka langkah selanjutnya yang akan ditempuh adalah mengadakan rapat bersama untuk membahas teknis pelaksanaan dari semua aspek pelayanan yang akan dilakukan pada waktu-waktu mendatang dengan membuat program kerja yang terpadu.

\footnotetext{
${ }^{23}$ Yakob Tomatala, PenatalayananGereja Yang Efektif Di Dunia Modern (Malang: Gandum Mas, 1993), 59.
} 


\section{Rapat Bersama}

Untuk melakukan suatu pekerjaan besar seperti hal memulai dan melaksanakan kerjasama pelayanan antargereja, perlu ada rapat bersama. Rapat bersama ini dimaksud untuk membahas cara kerja dan hasil apa yang akan dicapai. Rencana pelayanan dapat dibicarakan dalam rapat bersama ini, tetapi rapat bersama hanya sebatas alat. Yakub B. Susabda mengatakan,"Rapat hanyalah alat yang dipilih dan dipakai oleh gereja dengan sengaja untuk membantu kehidupan dan pelayanannya. Oleh karena itu selama peraturan-peraturan gereja mengenai rapat atau persidangan ini tidak bertentangan dengan kebenaran Firman Tuhan, kita harus bisa mempergunakannya dengan penuh tanggung jawab". ${ }^{24}$ Orang-orang yang diundang adalah para pemimpin gereja (gembala dan pelayan) dan ketua-ketua komisi dari setiap gereja lokal. Rapat bersama ini akan menjadi kerangka acuan untuk menciptakan relasi formal antargereja yang diwujudkan melalui kerjasama pelayanan antar gereja lokal di Doyo.

Materi rapat bersama ini menyangkut semua sistem pelayanan yang mau diterapkan, dibahas dan disetujui bersama. Hasil rapat ini akan dijadikan sebagai panduan atau pedoman dalam pelaksanaan persekutuan bersama anatargerreja lokal di Doyo Sentani.

Keputusan yang diambil dalam rapat bersama ini adalah keputusan semua gereja lokal dan semua gereja lokal wajib melaksanakannya. Untuk mensosialisasikan keputusan-keputusan itu, maka dalam rapat bersama ini memilih badan khusus untuk menangani semua urusan yang berkenaan dengan kerjasama pelayanan persekutuan antargereja lokal di Doyo Sentani.

\section{Penandatangan Surat Persetujuan}

Kerjasama pelayanan ini sifatnya antargereja dan tentu tidak terlepas dari masalah-masalah, baik internal maupun eksternal serta dampak negatif yang timbul dari persekutuan bersama antargereja lokal di Doyo Sentani, yang mungkin disebabkan oleh perbedaan persepsi. Untuk menghindari bahaya disintegrasi dalam persekutuan bersama perlu ada surat persetujuan yang isinya menyangkut pernyataanpernyataan penting.

Di dalam surat persetujuan bersama ini tertuang garis besar dari semua keputusan dan peraturan yang berhubungan dengan kegiatan kerjasama pelayanan antargereja. Tujuannya ialah sebagai tanda bukti bahwa kerjasama pelayanan antargereja sudah mendapat legitimasi dari semua pihak atau gereja lokal yang adadi Doyo Sentani.

\footnotetext{
${ }^{24}$ Yakub B. Susabda, Prinsip-Prinsip Pertimbangan Utama Administrasi Gereja (Malang: Gandum Mas, 1981), 73.
} 
Surat persetujuan atau pernyataan ini akan ditandatangani oleh semua gembala atau pelayan jemaat dengan membubuhi cap gereja masing-masing serta tembusan kepada badan pengurus daerah atau wilayah dari tiap-tiap gereja lokal di Doyo Sentani sebagai bukti persetujuan dari mereka.

Visi dan misi dari persekutuan bersama antargereja lokal di Doyo Sentani adalah meningkatkan mutu rohani jemaat. Untuk menjaga kemurnian visi dan misi ini, maka hal yang perlu diwaspadai adalah masalah perpindahan anggota jemaat ke gereja lain, karena hal itu sangat rawan dalam kehidupan bergereja, apalagi dalam konteks kerjasama pelayanan antargereja. Poin ini perlu dimasukkan dalam surat pernyataan bersama itu. Pada hakikatnya dalam hal hubungan kerjasama pelayanan antargereja di Doyo Sentani yang diupayakan secara bersama ini tidak menghendaki hal tersebut, karena hal itu bukanlah tujuan utama. Kalaupun hal itu terjadi akan diproses berdasarkan anggaran dasar dan anggaran rumah tangga gereja yang bersangkutan.

\section{Pelaksanaan Kegiatan}

Persekutuan bersama antargereja lokal di Doyo dapat dilaksanakan secara bergiliran dari gereja ke gereja. Diharapkan semua gereja lokal yang ada di Doyo Sentani mendapat kesempatan untuk dilayani dan melayani atau ditentukan pada suatu tempat tertentu yang disetujui oleh semua gereja lokal yang ada di Doyo. Hal-hal yang perlu diperhatikan dalam pelaksanaan persekutuan bersama antargereja yaitu:

Pertama, waktu pelaksanaan. Waktu pelaksanaan dapat diatur atau disesuaikan dengan kalender pelayanan setiap gereja lokal supaya tidak menghalangi kegiatan pelayanan rutin dalam gereja masing-masing. Waktu pelaksanaan diharapkan supaya tidak bersamaan dengan kegiatan dalam gereja lokal, karena hal itu dapat memengaruhi anggota jemaat karena tidak dapat hadir dalam persekutuan bersama antargereja lokal di Doyo Sentani.

Kedua, orang-orang yang terlibat dalam pelayanan. Secara otomatis gembala atau pelayan jemaat dari semua gereja lokal, hamba-hamba Tuhan dari luar (pengkhotbah tamu), dan aktivis gereja yang diseleksi berdasarkan persyaratan Alkitab (I Timotius 3:1-7) yang berhak atau patut melayani firman. Dalam persekutuan bersama antargereja ada rasa kebersamaan yang harmonis yang mungkin tidak pernah didapatkan dalam gereja masing-masing. Rasa kebersamaan ini tampak dalam hal saling mengenal satu sama lain, saling menguatkan iman, saling mendoakan, saling membagi pengalaman, saling membangun, saling melengkapi dan saling melayani di antara sesama orang percaya sebagai anggota tubuh Kristus yang am. Eddy Paimoen mengatakan, 
Fungsi gereja sudah berubah, dari tubuh Kristus - persekutuan orang percaya - menjadi seperti supermarket atau sebuah restoran atau sebuah arisan. Alkitab menekankan dan menggarisbawahi tentang persekutuan dan keberssamaan di dalam gereja. Suasana itu semakin lama sudah semakin berkurang dan kemungkinan besar suasana itu akan menghilang. Suasana kasih lintas batas telah dialami oleh gereja purba, dirasakan semakin primordial. ${ }^{25}$

Pola hidup jemaat mula-mula adalah contoh konkrit yang patut diteladani oleh gereja pada masa kini. Kehidupan jemaat mula-mula hidup dalam suasana persekutuan yang harmonis serta hidup saling melayani tanpa membeda-bedakan diantara mereka. Hubungan yang harmonis itu terjalin karena mereka semua sehati sejiwa. Prinsip kebersamaan jemaat mula-mula relevan untuk segala zaman dan tempat. Itulah yang Tuhan mau tercipta di Doyo Sentani supaya gereja-Nya dapat menikmati berkat-Nya.

\section{Evaluasi}

Evaluasi berarti menilai kembali apakah hasil yang diharapkan sudah tercapai atau belum mencapai hasil maksimal. Yakub B. Susabda mengatakan, "Langkah terakhir dari pertanggungjawaban administrasi gereja ialah evaluasi. Langkah ini sebetulnya bertujuan untuk menciptakan suatu diskusi terbuka untuk program yang sedang dan telah dilaksanakan, untuk sesuatu yang lebih baik."26

\section{Pertumbuhan Gereja}

Akibat dari optimalnya hubungan antar gereja di Doyo Sentani yang didukung oleh peran serta semua gereja-gereja lokal itulah yang menyebabkan pertumbuhan gereja, baik secara kualitas maupun kuantitas. Inilah hasil yang diharapkan untuk dicapai melalui optimalisasi hubungan antargereja.

Dua aspek pertumbuhan yang akan ditelaah lebih mendalam ialah gereja bertumbuh secara kualitas dan gereja bertumbuh secara kuantitas dengan berpedoman pada prinsip Alkitab.

\section{Gereja Bertumbuh secara Kualitas}

Aspek kualitas menyangkut pertumbuhan gereja ke dalam, yaitu meningkatnya pertumbuhan atau mutu rohani jemaat menjadi sama seperti Kristus. Mencapai fase sama seperti Kristus melalui pembinaan

\footnotetext{
${ }^{25}$ Eddy Paimoen, Kerajaan Allah dan Gereja (Bandung: Agiamedia, 1999), 51.

${ }^{26}$ Yakub B. Susabda, Prinsip-Prinsip Pertimbangan Utama Administrasi Gereja (Malang: Gandum Mas, 1981), 68.
} 
serta penyerahan diri secara total kepada Allah yang oleh Roh Kudus menuntun setiap orang mencapai kedewasaan penuh dalam Kristus. Hasil secara kualitas yang diupayakan gereja-gereja lokal melalui penerapan pola pembinaan yang efektif diharapkan dapat memproduksi kualitas atau mutu rohani jemaat yang tetap solid. Yakob Tomatala mengatakan, "Pertumbuhan rohani dan dampak yang diharapkan terjadi di sini ialah agar ada perubahan konsepsi oleh Kristus tentang Kristus, yang dengan sendirinya akan merubah kelakuan Kristen, menuju kehidupan yang bertanggungjawab." 27 Berarti hanya orang yang pikirannya sudah diubahkan oleh Kristus yang dapat memahami tentang Kristus dan kebenaran-Nya yang tertulis dalam Alkitab.

Persekutuan bersama antargereja lokal di Doyo Sentani dapat meningkatkan pertumbuhan gereja secara kualitas. Unsur-unsur yang menunjang pertumbuhan gereja lokal secara kualitas adalah keterlibatan semua anggota jemaat mengikuti persekutuan bersama antar gereja yang di dalamnya ada pujian penyembahan kepada Tuhan, doa bersama atau individu, mendengarkan firman Tuhan adan melakukan firman itu dalam kehidupan sehari-hari. Dampaknya gereja lokal bertumbuh secara kualitas.

Wawancara dengan bapak Rudy Ebe (Sekretaris PAM Gereja Kristen Injili Jemaat Laharoi Doyo Baru) membuktikan hal ini. Rudy Ebe mengatakan, "Dengan adanya persekutuan bersama antar gereja di Doyo dapat membina dan meningkatkan rohani anggota jemaat setempat atau gereja lokal." ${ }^{28}$

\section{Gereja Bertumbuh secara Kuantitas}

Aspek kuantitas menyangkut pertumbuhan gereja di luar, yakni bertambahnya jumlah anggota jemaat yang diselamatkan menjadi anggota yang bertanggung jawab terhadap semua pelayanan gereja dan melakukan semua kewajiban sebagai anggota jemaat yang sah.

Persekutuan bersama antar gereja lokal di Doyo Sentani mempunyai daya tarik yang kuat bagi anggota jemaat yang tidak aktif karena dengan berkumpul bersama, mereka tidak merasa malu dan saling mendorong supaya terbiasa dan lama-kelamaan mereka menjadi aktif atau rajin berakti dengan saudara seiman lainnya, baik dalam persekutuan bersama maupun dalam gereja asalnya di mana mereka terdaftar.

\footnotetext{
${ }^{27}$ Yakob Tomatala, Penatalayanan Gereja yang Efektif di Dunia Modern (Malang: Gandum Mas, 1993), 38.

${ }^{28}$ Rudy Ebe, Wawancara oleh Penulis, Sentani Jayapura, Papua 20 Desember 2011.
} 
Peningkatan pertumbuhan gereja secara kuantitas diwujudkan dalam persatuan. Gereja mula-mula jumlahnya bertambah terus karena mereka hidup dalam satu kesatuan yang utuh dan harmonis, sehingga Tuhan menambahklan jumlah mereka dengan orang yang diselamatkan. Kenyataan bahwa di Doyo Sentani banyak orang Kristen, secara khusus kaum muda meninggalkan gereja dan jauh dari Tuhan, sehingga akibatnya pertumbuhan gereja secara kuantitaspun menurun drastis.

Dalam mengoptimalkan hubungan kerjasama pelayanan antargereja lokal di Doyo Sentani melalui persekutuan bersama, penulis berharap agar upaya ini dapat menambah untuk memaksimalkan pelayanan gereja lokal yang selama ini mengalami kendala dalam menjangkau anggota jemaatnya yang tidak aktif. Melalui persekutuan bersama antargereja ini diharapkan supaya ada peningkatan dalam pertumbuhan gereja lokal di Doyo Sentani secara kuantitas.

Wawancara dengan bapak Ringgo Marweri (Majelis Gereja Kristen Injili Jemaat Laharoi Doyo Baru) mengatakan, "Sangat penting sekali persekutuan bersama, karena dengan persekutuan bersama saudara-saudara yang selama ini hidupnya lupa akan Tuhannya boleh diikutsertakan." ${ }^{29}$

Pertumbuhan gereja, baik secara kualitas maupun secara kuantitas merupakan tujuan yang hendak dicapai dari optimalisasi hubungan antargereja di Doyo Sentani. Roh Kuduslah yang memakai gereja-gereja di Doyo Sentani untuk mencapai tujuan mulia ini, tanpa karya Roh Kudus dalam gereja-Nya tidak akan ada pertumbuhan, sebab Roh Kudus adalah dinamika dari pertumbuhan gereja.

${ }^{29}$ RinggoMarweri, Wawancara oleh Penulis, sentaniJayapura, Papua Barat, 31 Desember 2011. 


\section{PENUTUP}

\section{Kesimpulan}

Pertama, Alkitab menyatakan bahwa semua orang percaya dari berbagai latar belakang bangsa, suku, bahasa, budaya adalah satu dalam Kristus. Orang percaya dari segala zaman dan tempat sudah dipersatukan oleh Kristus melalui pengorbanan-Nya di kayu salib. Refleksinya dapat tampak melalui kerjasama pelayanan antargereja sebagai wujud dari kesatuan tubuh Kristus.

Kedua, Kesatuan dalam hubungan kerjasama pelayanan antargereja di Doyo Sentani dapat tercipta apabila semua orang percaya sungguhsungguh memahami arti persekutuan yang dimaksudkan oleh Tuhan Yesus Kristus. Persekutuan di antara orang percaya yang Yesus kehendaki ialah di dalamnya ada kesadaran untuk saling menerima, sehingga refleksinya orang percaya atau gereja lokal di Doyo Sentani hidup saling memperhatikan dan saling melayani tanpa membedabedakan gereja. Kurangnya pembinaan rohani menyebabkan gerejagereja lokal di Doyo Sentani tidak bertumbuh sebagaimana mestinya.

Persekutuan bersama antargereja lokal di Doyo Sentani suatu upaya untuk menunjang pertumbuhan gereja, baik secara kualitas maupun secara kuantitas. Persekutuan bersama antargereja lokal di Doyo Sentani merupakan suatu kebutuhan dan kekuatan bagi gereja lokal untuk dapat bertumbuh.

Optimalisasi hubungan kerjasama pelayanan melalui persekutuan bersama antargereja lokal di Doyo Sentani dapat dicapai karena hal itu merupakan kebutuhan. Persekutuan antargereja relevan untuk konteks pelayanan di Doyo Sentani. Pemimpin gereja dan anggota jemaat yang memahami kepentingan dari persekutuan bersama dapat mewujudkannya melalui pengoptimalisasian hubungan kerjasama antargereja lokal di Doyo.

Hubungan antargereja sebagai upaya dan sarana untuk mengkomunikasikan Injil Yesus Kristus bagi anggota jemaat yang tidak aktif, serta meningkatkan mutu rohani jemaat secara menyeluruh. Kebenaran yang disampaikan dalam persekutuan bersama ini dapat memperbaiki tingkah laku jemaat yang tidak berkenan kepada Tuhan dan mengarahkan anggota jemaat kepada kedewasaan penuh dalam Kristus. Selain anggota jemaat yang tidak aktif, orang yang di luar pun menjadi target pelayanan dari badan kerjasama pelayanan antar gereja lokal di Doyo. 


\section{KEPUSTAKAAN}

Buku-buku

Brill, J. Wesley. Tafsiran Injil Yohanes. Bandung: Kalam Hidup, 1995.

Christian, Jonge De. Menuju Keesaan Gereja. Jakarta: BPK Gunung Mulia, 2010.

Engstrom, Ted W. \& Edward R. Dayton, Seni Manajemen bagi Pemimpin Kristen. Bandung: Kalam Hidup, 2007.

Kartono, Kartini. Pengantar Metodologi Riset. Bandung: Mandar Maju, 1990.

Mohr, Walter. Anda Dan Gereja. Surabaya: YAKIN, n.d.

Paimoen, Eddy. Kerajaan Allah dan Gereja. Bandung: Agiamedia, 1999.

Roni, Yusuf. Berbicara tentang Kesatuan Gereja. Yogyakarta: Yayasan ANDI, 1993.

Singarimbun, Masri dan Sofyan Effendi, MetodePenelitianSurvei. Jakarta: LLP3ES, 1989.

Susabda, Yakub B. Prinsip-Prinsip Pertimbangan Utama Administrasi Gereja. Malang: Gandum Mas, 1981.

Tomatala, Yakob. Penatalayanan Gereja yang Efekti fdi Dunia Modern. Malang: Gandum Mas, 1993.

Tomatala, Yakob. Kepemimpinan yang Dinamis. Malang: Gandum Mas, 2005.

Usman,Husaini dan Setiady, R. Purnomo A. Pengantar Statistika. Jakarta: BumiAksara, 2003.

Wagner, C. Peter. Gereja Saudara Dapat Bertumbuh. Malang: Gandum Mas, 1990.

\section{Wawancara}

Suebu, Barnabas. "Injil dan Masyarakat Sentani," Ceramah: Disampaikan pada Sidang Klasis GKI Sentani. Ifale Tanggal 3-6 Nopember 1999), Sentani Jayapura Papua.

Ebe, Rudy. Wawancara oleh Penulis. Sentani Jayapura, Papua, 20 Desember 2011.

Marweri, Ringgo. Wawancara oleh Penulis. Sentani Jayapura, Papua, 31 Desember 2011. 